\title{
Frames of Rights, Entitlement, Need, and Deservingness in the Affordable Care Act
}

\author{
Susanne N. Beechey \\ Whitman College, Walla Walla, WA, USA \\ Email: beechesn@whitman.edu
}

Received 30 July 2015; accepted 27 September 2015; published 30 September 2015

Copyright (C) 2015 by author and Scientific Research Publishing Inc.

This work is licensed under the Creative Commons Attribution International License (CC BY). http://creativecommons.org/licenses/by/4.0/

c) (i) Open Access

\begin{abstract}
I analyze four frames deployed by members of United States Congress on the floor of the House of Representatives before the initial passage of the Affordable Care Act on November 7, 2009. Of the four frames-need, rights, deservingness, and entitlement-need was by far the most commonly used frame in the debate followed by rights, deservingness, and entitlement. I conclude that while Congress may broadly agree that Americans need and even deserve health care, it provided no right or entitlement to care under the Affordable Care Act.
\end{abstract}

\section{Keywords}

Health Care, Frames, US Congress, Rights, Entitlement, Need, Deservingness

\section{Introduction}

Entitlement, deservingness, need, and rights are distinct yet interrelated concepts in US social policy. Entitlement and right can sometimes be synonymous, as the right to or entitlement to benefits as specified by law. Entitlement can also refer to a sense of self deservingness. Sometimes entitlement to a benefit requires demonstration of financial need, as in the pre-TANF world of welfare policy. Deserving generally refers to merit or worth. Distinctions are often made between those who do or do not deserve an entitlement they receive. Need is often part of a calculation of deservingness, though sometimes need is not sufficient to merit deservingness. A right can be a power or privilege to which one is entitled, as in the right to vote. Sometimes individuals might have a right, or property claim to something, but be seen by some as undeserving of that benefit. These are sometimes labeled "special rights" in the US. Sometimes rights language is used to refer to meeting basic needs, as in the right to shelter or the right to health care, though this usage is generally devoid of any legal entitlement to enforce the sense of universal deservingness of the fulfillment of basic needs. Each term presents a different relationship between the citizen and the state. Rights and entitlements may include legal means to enforce benefits, 
while the statuses of need and deserving do not come with enforcement mechanisms.

Different policy areas have been more or less associated with each of these concepts. Welfare, or cash benefits for poor families, has always been a need-based program. That is, significant financial need, along with other eligibility criteria, must be demonstrated in order to access these benefits. Social Security (Old Age and Survivor Benefits), on the other hand, has never had a need-based component. Benefits are calculated without regard for other sources of income and wealth. However, Social Security benefits play a significant role in reducing poverty, lifting 15 million elderly Americans above the poverty line, so meeting need is part of what the program does (Van de Water \& Sherman, 2013). Some government health insurance programs have need-based eligibility criteria, such as Medicaid and State Children's Health Insurance Programs (SCHIP), while others like Medicare do not. The Affordable Care and Patient Protection Act (ACA) includes need-based subsidies to meet the universal requirement for individual health insurance coverage.

The 1996 welfare reform is often described as ending the individual entitlement to welfare by placing a 5 year lifetime limit on benefit receipt for adults (Weaver, 2000). Social Security and Medicare are often referred to as entitlement, both in the sense of guaranteed benefits for those who meet eligibility criteria and in the sense of budgeted separately from discretionary spending in the federal budget. The Affordable Care Act turned entitlement on its head by mandating individual purchase rather than entitling individuals to health care or health insurance coverage.

Social Security tends to be discussed as an entitlement, earned through paying into the system during working years, rather than framed as a right. Health care is sometimes referred to as a human right, as in the United Nations International Covenant on Economic, Social, and Cultural Rights, but in the United States there is no legal right to health care. While the National Welfare Rights Organization (NWRO) fought to frame welfare as a right, the program is rarely thought of in those terms today (Nadasen, Mittelstadt, \& Chappell, 2009). Advocates did succeed arguing in court that other rights applied in the administration of welfare, as in King v. Smith (1968) and Goldberg v. Kelly (1970), as well as for Social Security in Weinburger v. Wiesenfeld (1975).

When created in 1935 welfare benefits, then Aid to Dependent Children, were seen as non-controversial, particularly because these beneficiaries were seen as deserving of the benefits they received; yet the politics of the program shifted as the public face of these benefits shifted from a white widow to an unmarried woman of color (Abramovitz, 1988; Gilens, 2000; Mink, 1998). Social Security, on the other hand, was controversial when enacted. Social Security was designed around benefits based on contributions to the system, in part to construct recipients as deserving of their benefits (Derthick, 1979). The receipt of Social Security benefits has created a strong political base of senior citizen voters whose political power and positive construction contribute to the notion that Social Security recipients deserve the benefits they receive (Campbell, 2003). While there is wide general agreement that everyone deserves health care, the question of who must provide is less clear (Willen, 2012).

\section{Data and Methods}

Contemporary social policy debates in the United States frequently include talk of rights, entitlement, need, and deservingness. Each of these concepts frame policy beneficiaries in a different relationship to the state. In this paper I coded and analyzed the remarks of members of Congress for their use the frames of rights, entitlement, need, and deservingness, in order to better understand how these concepts frame contemporary social policy debate in the United States. I analyze debates on the floor of the United States Congress, as captured on the Congressional Record. I focus on the floor debate in the House of Representatives before the initial passage of the Affordable Care Act on November 7, 2009. I ask, how are the frames of rights, entitlement, need, and deservingness mobilized by members of Congress in this debate? How, if at all, do these usages vary by party and policy position? What are the implications of these frames for the policy outcome?

The Congressional Record is the official record of policy debates in the United States Congress. To be sure much deliberation and actual vote wrangling happens behind closed doors rather than on the floor, yet the Congressional Record is still a useful record for the accepted political ideas around a policy debate. Floor speeches have multiple audiences_-other members of Congress, constituents, interest groups, and national media. Speeches are sometimes carefully scripted, with references to policy reports or newspaper articles, other times they include references to constituents or ways an issue affects their home state or district. Sometime speeches are little more than a repetition of talking points from the party or caucus, and other times speeches seem more 
like stream of consciousness rambling. In all cases, these speeches reflect the politically palatable ideas informing a policy debate. For this reason, studying the words of members of Congress can be a good window into the broader policy discourse. While some scholars distinguish between the words as spoken on the floor and those inserted in the record after the fact, for my purposes both offer windows into the ideas informing a policy debate.

\section{Health Care Reform}

During the November 7, 2009 health care reform debate on the floor of the House, the frames of need, deservingness, rights, and entitlement appeared 336 times (United States Congress, 2009). This includes multiple usages by some members of Congress, who spoke multiple times or whose speeches included multiple frames. Need was by far the most common frame with 207 occurrences, making up 62\% of the frames analyzed. Rights frames were used 62 times or 18\% of the total. Deservingness frames appeared 45 times, composing $13 \%$ of the total. Entitlement was the least common frame with only 22 instances or $7 \%$ of the total frames.

\subsection{Need}

In the health care reform debate, need was by far the most commonly used of the four frames. Both Democrats and Republicans mobilized this frame, though toward different ends and with different foci. The most common need frame (63 instances) was the need for health care, either in general or with reference to a specific health care need, contributing about $30 \%$ of the need frames. The majority of these instances came from Democrats (75\%). For example, Representative Thompson (D-CA) argued, "Mr. Speaker and Members, for far too long too many Americans have not had access to quality, affordable health care. Because of this legislation, the millions of Americans who don't have health care or who are struggling to pay their health care bills will be able to get the care they need when they need it.” Representative McCollum (D-MN) concurred, “Our health care system is broken when 45,000 people die in the United States each year because they lack health insurance and cannot access needed care.” While Democrats had a broader view of the need for health care, Republicans tended to present a more constrained view of health care needs. For example, Representative Ehlers (R-MI) argued Democrats should work with Republicans to, "try to produce a bill that is good for the country, for the people, and especially for those who need medical care.” Similarly, in arguing for provisions in the Republican substitute bill, Representative Reichert (R-WA) distinguished between levels of need "These solutions bring lower costs and bring health care to those who really need it.”

A quarter of the need frames (51 instances) argued for the need for health care reform, with Democrats arguing for the passage of the Affordable Care Act and the Republicans concurring that health care reform was necessary but this was the wrong bill. Representative Ackerman (D-NY) argued, "Let me be absolutely clear: every single American should have access to affordable and quality health-care coverage. For too many years, drastically needed health-insurance reform has been delayed.” Representative Gene Green (D-TX) concurred, "We are in desperate need of health care reform. Health insurance premiums are growing three times as fast as wages; and, last year, more than half of Americans postponed medical care or skipped their medications because they couldn't afford them." While Democrats argued for the need for reform to support the passage of the bill, Republicans concurred with the need for reform, but disagreed on what that reform should look like. For example, Representative Herger (R-CA) commented, "We all agree that we need health care reform, but we don't need to put the government in charge. Mr. Speaker, I believe in the free market, I believe in choice and competition, and I believe in freedom to choose your doctor and to get the treatments you need.” The debate hinged less on whether reform was needed but what type of reform. The remaining need frames included the need for health care workers, emergency rooms, jobs, tort reform, and tax cuts, among others.

\subsection{Rights}

Rights framing appeared 62 times during the debate before the passage of the Affordable Care Act in the House. The most common frame was the right to health care (25\%), followed by arguments for reproductive rights with regard to the Stupak amendment (20\%), and consumer rights to choose (13\%). Democrats made all of the arguments framing a right to health care. For example, Representative Davis (D-IL) argued, "I believe that health care ought to be a right and not a privilege.” Representative Clarke (D-NY) agreed, "Every American has a hu- 
man right to adequate physical and mental healthcare, and I believe that government has a responsibility to assist its citizens in securing quality healthcare... Healthcare is a fundamental human right, rather than a commodity.” While the bill did not include a legal right to health care, but rather an individual mandate to purchase insurance, the frame was popular with Democrats.

Republicans countered the right to health care with a frame of a consumer's right to choose. For example, Representative Sam Johnson (R-TX) argued, "Real health reform protects a patient's right to choose their own care. Real health reform gives doctors the freedom to do what is best for their patients.” His colleague, Representative Boozman (R-AR) agreed, "I have heard my constituents and the American people and they say they don't want this government takeover. They want the right to make their own health care choices.” While the right to health care appeared in the debate almost twice as often, the right to make health care choices was a prominent theme for Republicans.

In debate against the Stupak amendment, which sought to prohibit the use of federal funds to pay for abortion or cover any part of the costs of a health plan that includes abortion coverage, pro-choice Democrats, primarily Democratic women, made frequent references to reproductive rights, contributing $20 \%$ of all rights frames. Representative DeGette (D-CO) cautioned, "If enacted, this amendment will be the greatest restriction of a woman's right to choose to pass in our careers.” Representative Lowey (D-NY) concurred, "This amendment threatens the rights and health of women to seek a legal procedure covered by the premiums they will pay out from their own pockets.” Unlike the right to health care frames, the reproductive rights frames were rarely answered with other rights claims, such as a right to life, though this certainly is common in broader abortion discourse (Ferree, Gamson, Gerhards, \& Ruchts, 2002).

\subsection{Deservingness}

Deservingness frames appear 45 times in the debate. Over half of those (53\%) make the argument that Americans deserve health care. This frame was more frequently used by Democrats (75\%) arguing in support of the Affordable Care Act, while Republicans used the frame to argue for a different vision of health care reform. Representative Baldwin (D-WI) made a typical, if generic, case, "Today, we declare with conviction: every American deserves health care, and every American shall have it.” Representative Olver (D-MA) extended the argument, "This is a historic time in our country's history. This bill makes the critical investments that are needed to turn our health care system around and provide the health care that our citizens deserve.” Many Democrats made general claims about all Americans deserving health care as a basis for supporting ACA.

Republicans, on the other hand, would sometimes concur that everyone deserves health care but then argue that ACA was the wrong vehicle to deliver necessary reform. Representative Ros-Lehtinen (R-FL) offered one example: "The trillion dollar Pelosi bill makes it tougher on seniors to get the coverage and treatment they deserve after a lifetime of hard work and sacrifice.” Another Republican approach was characterized by Representative King (R-IA): "I would like to say first, as the gentleman from Georgia stated, all Americans deserve health care, that all Americans have health care, every single one. Eighty-five percent of us are insured and 85 percent of us are happy with the policy that we have." King declared that all Americans not only deserve, but indeed have, health care, and then turns his attention to focus on the interests of those who have health insurance and do not want to see it change. Rather than argue that one group does not deserve health care, instead King and others argued another group deserves something else, like no change in their health insurance.

Democrats challenged this frame by arguing Americans deserve health insurance, placing those interests above those who want no change in their insurance. Representative Ackerman (D-NY), for example, argued Americans deserve the protections that will come with health insurance reform, "I support this landmark legislation because it changes the way that insurance companies ration medical care... All Americans deserve these basic protections from their health-insurance plans and these important guarantees will improve the coverage for nearly all those who already have insurance-even those Americans who are extremely satisfied with their current plans.” Republicans retorted these with a generic claim that Americans deserve better. Representative Tiberi (R-OH) declared, “Americans deserve better, Mr. Speaker. There is a better way. Let's reject this bill and start over.”

Representative Kline (R-MN) concurred, “The American people deserve better. Let’s vote 'no' on this power grab by Washington bureaucrats.” While Democrats used deservingness frames more frequently, the deservingness claims made by both parties were similarly vague and generic. Rarely were claims made that specific indi- 
viduals or groups deserved. Never was an explicit claim made that a group or individual did not deserve health care. However, the idea of a group undeserving of health care was implicit in the exclusion of undocumented immigrants from health care reform. In this debate, the undeserving were not explicitly marked, but the concept of those undeserving of assistance from the state functioned throughout the debate.

\subsection{Entitlement}

Of the 22 usages of the entitlement frame, most (77\%) were deployed by Republicans. Most of these usages of the entitlement frame were pejorative. Republicans used this frame to argue that health care reform was creating a new entitlement or expanding existing entitlements, when instead the Congress should be focused on entitlement reform. For example, Representative Posey (R-FL) argued, "Sadly, this health care bill creates a new unaffordable entitlement program that we cannot afford and will indebt future generations of Americans for decades to come.” Representative Brown-Waite (R-FL) concurred with a similar argument, "Mr. Speaker, the bill before us creates 111 different offices, bureaus, commissions, programs and entitlements, but it only cuts oneMedicare. This bill steals more than $\$ 500$ billion from our Nation’s seniors to fund new entitlement programs for the young, the healthy and the wealthy.” Democrats countered with the argument that health care reform was in fact entitlement reform. Speaker Pelosi (D-CA) countered, "President Obama has said that health care reform is entitlement reform, and this legislation proves that point. It is fiscally sound, it is paid for, and it reduces the deficit by tens of billions of dollars over the next 10 years.” Representative Bishop (D-GA) made a similar defense of health care reform as entitlement reform: "The key to fiscal stability is entitlement reform. The key to entitlement reform is health care reform, and the first step in health care reform is the legislation before us.” When using entitlement to refer to a type of government program the usage was pejorative for both Democrats and Republicans as the debate centered on whether health care reform was extending or reforming entitlements.

In a rare positive usage of entitlement, Delegate Faleomavaega, a Democrat from American Samoa, argued that every American is entitled to health care: "The Affordable Health Care for America Act, H.R. 3962, carries with it our expectations and hopes for quality and affordable health care for our people and with it a commitment; a commitment to ensure that every American is provided quality health care that they are entitled to and to receive health services that they so critically need." Representative Farr (D-CA) too made a positive usage of entitlement to argue against the Stupak amendment, "I rise to express my strong opposition to the Stupak-Pitts amendment... If we want health care for all Americans then women should be entitled to all health care, not just some aspects of it.” Representative Bono Mack (R-CA) also used a positive notion of entitlement to argue against the bill because it would place the power to decide treatment and care in the hands of the federal government. "This bill does not offer real health care reform. Rather than reduce costs and make health care more affordable and accessible, this bill will increase costs to consumers and put the government in charge of deciding what treatment and care Americans are entitled to.” For the most part entitlement was a pejorative frame, though there were a few instances where citizens were portrayed as entitled to health care, or entitled to make their own decisions regarding health care.

\section{Conclusions}

Of the four frames - need, rights, deservingness, and entitlement-need was by far the most commonly used frame in the debate leading up to the initial passage of the Affordable Care Act in the House of Representatives, followed by rights, deservingness, and entitlement. The four frames rarely co-occurred in the same argument. When they did co-occur it was most often with need. Need and deserve co-occurred most frequently with 7 instances, all in comments by Democrats. Need and entitlement co-occurred twice in arguments by Democrats, while need and rights were used in the same argument by one Democrat and one Republican. Deservingness and rights co-occurred twice, both by Democrats. Entitlement did not co-occur with rights or deservingness. Indeed overall entitlement functioned differently from the other three frames. Most often this frame was pejorative. Though entitlement can be understood as similar to a right, in this debate, entitlement was pejorative while right was positive in usage.

With the exception of entitlement, the frames were used in similar manners, despite rarely being used together. Half of all frames (104 instances) were used to make generic claims about the relationship of Americans to health care, most commonly as in "Americans need health care” (63 instances), less commonly as deserving (24 instances), only sometimes as a right (15 instances), and rarely as an entitlement (2 instances). While overall 
rights claims were more common than deservingness frames, those rights frames tended to be specific while the deservingness frames tended to be generic statements that “Americans deserve health care”. The frames generally referred to a generic group of “Americans” rather than specifying a particular group. When groups were specified, they included women, seniors, and veterans, as well a generic references to the constituents of a particular state.

Need was used more frequently than rights, deservingness, or entitlement to describe the relationship of citizens to health care. To say there is a need, is to define a problem, but not necessarily a public policy problem. Certainly part of what Democrats are doing, particularly since this is a debate directly before a vote on a significant piece of legislation, is arguing that this need is indeed a public policy problem to which the state should respond. But this is a weaker claim than to assert a right, though some progressive Democrats did make this claim. Right implies that this is an issue of public policy to which the state has an obligation to respond. To describe a need is not the same as declaring the state responsible for meeting that need. Indeed this tension is clear in the Affordable Care Act itself. ACA provides no right or entitlement to health care as universal health care was dropped relatively quickly in the debate. The final legislation is a mandate for individuals to purchase their own health insurance with the state providing some coordination of the market, regulation of the industry, and subsidies for purchase to those who demonstrate financial need. Congress may broadly agree that Americans need and even deserve health care, but it provided no right or entitlement to care under the ACA.

\section{References}

Abramovitz, M. (1988). Regulating the Lives of Women. Boston: South End Press.

Campbell, A. (2003). How Policies Make Citizens: Senior Political Activism and the American Welfare State. Princeton, NJ: Princeton University Press. http://dx.doi.org/10.1515/9781400841318

Derthick, M. (1979). Policymaking for Social Security. Washington, DC: Brookings Institution.

Ferree, M., Gamson, W., Gerhards, J., \& Ruchts, D. (2002). Shaping Abortion Discourse: Democracy and the Public Sphere in Germany and the US. New York, NY: Cambridge University Press. http://dx.doi.org/10.1017/CBO9780511613685

Gilens, M. (2000). Why Americans Hate Welfare: Race, Media, and the Politics of Antipoverty Policy. Chicago, IL: University of Chicago Press.

Mink, G. (1998). Welfare's End. Ithaca, NY: Cornell University Press.

Nadasen, P., Mittelstadt, J., \& Chappell, M. (2009). Welfare in the United States: A History with Documents 1935-1996. New York, NY: Routledge.

United States Congress (2009). Congressional Record, 155, H12592-H12968. 7 November 2009. http://www.gpo.gov/fdsys/pkg/CREC-2009-11-07/pdf/CREC-2009-11-07.pdf

Van de Water, P., \& Sherman, A. (2013). Social Security Keeps 22 Million Americans Out of Poverty: A State-by-State Analysis. Washington DC: Center on Budget and Policy Priorities.

http://www.cbpp.org/research/social-security-keeps-22-million-americans-out-of-poverty-a-state-by-state-analysis

Weaver, K. (2000). Ending Welfare as We Know It. Washington DC: The Brookings Institution.

Willen, S. (2012). How Is Health-Related “Deservingness” Reckoned? Perspectives from Unauthorized Im/migrants in Tel Aviv. Social Science \& Medicine, 74, 812-822. http://dx.doi.org/10.1016/j.socscimed.2011.06.033 